\title{
FACTORS DETERMINING SEASONAL VARIATIONS IN TRAFFIC VOLUMES
}

\section{SPLAWIŃSKA ${ }^{1}$}

\begin{abstract}
The characteristics of seasonal variations in traffic volumes are used for a variety of purposes, for example to determine the basic parameters describing annual average daily traffic - AADT, and design hourly volume - DHV, analyses of road network reliability, and traffic management. Via these analyses proper classification of road sections into appropriate seasonal factor groups (SFGs) has a decisive influence on results. This article, on the basis of computational experiments (models of artificial neural networks, discriminatory analysis), aims to identify which factors have the greatest impact on the allocation of a section of road to the corresponding SFG, based on short-term measurements. These factors are presented as qualitative data: the Polish region, spatial relationships, functions of road, cross-sections, technical class; and quantitative data: rush hour traffic volume.
\end{abstract}

Keywords: roads, traffic volume, traffic management, classification of traffic volume, data collection

\section{INTRODUCTION}

Continuous automatic recording of traffic behaviours provides valuable information necessary for the planning, design, and maintenance of road sections and intersections. This allows for the direct determination of the basic parameter describing traffic that is the Annual Average Daily Traffic (AADT). AADT indicates the number of vehicles passing through a given section of road in a 24hour period, on average, over the span of one year. In addition, thanks to the continuous recording of traffic, it is possible to determine seasonal traffic variations, allowing for the execution of a simplified conversion of traffic volumes from short-term measurements into AADT

\footnotetext{
${ }^{1}$ PhD., Eng., Cracow University of Technology, Faculty of Civil Engineering, ul. Warszawska 24, 31-155 Krakow, Poland, e-mail: msplaw@pk.edu.pl
} 
(on road sections where permanent counters - PTCs - are not installed). In practice, the division of the road network into the so-called seasonal factor groups (SFGs) is performed and the conversion factors of daily traffic volumes into AADT are determined (the share of the monthly average daily traffic in the annual average daily traffic). In addition, these characteristics (profiles of seasonal variations) are used in road network reliability analysis [17], in the new approach of determining design volumes based on generalized costs (economic analyses) [2], and in making decisions within the Intelligent Transportation Systems and general traffic management. The most effective way of grouping sections of roads is through a combination of expert knowledge (on the basis of functional/geographical placement $[3-5,13,15,16,22])$ with one of the mathematical methods (cluster analysis, discriminant analysis, multiple linear regression, genetic algorithms, artificial neural networks, or hybrid models such as the combination of the fuzzy sets theory with neural networks [1, $4,5,6,8,9,10,12])$. As explanatory variables, data describing road sections (functional class, location, number of lanes), road users (traffic character, destination), and demographic and socioeconomic characteristics are commonly used. The predominant criterion is data on trip-purpose and trip-length characteristics (division of rural roads into commuter, business, long distance, recreational). This information can only be acquired directly from road users via interview surveys, or from Floating Car Data (data not commonly available). It should also be noted that due to the uncertain relationship between the optimal number of seasonal factor groups and the explanatory variables, there is no clear answer as to how many groups there should be. According to US guidelines $[1,5]$, the most common number of groups found in existing literature is between 3 and 5 . This is a compromise between the accuracy of estimating values on their basis (using typical traffic variation profiles) and the possibility of defining the attributes of the classification of the road to a given group. Currently, in Poland, two SFGs are defined [14]: roads of economic and tourist-recreational nature traffic patterns (typical profiles of seasonal variations are available on the official GDDKiA website [24]), which in light of previous studies $[18,19]$ seems to be too general. Classification of sections into a given group is based on Sunday and holiday traffic. Roads of an economic nature are characterized by low seasonal traffic variations (summer time) and average daily traffic on Sundays, which is $140 \%$ lower than the average daily traffic on weekdays, while roads of a tourist-recreational nature are characterized by increased traffic in the summer months (VII, VIII); $40 \%$ higher than the AADT, and average daily traffic on Sundays $40 \%$ higher than the average daily traffic on weekdays. Naturally, this data is very imprecise and difficult to determine without observing traffic volumes across a longer period of time. Although F. Zhao, M. Li, and L. Chow proposed a fuzzy decision tree to assign road sections into SFG [23], this method requires a lot of input data (including the percentage 
of seasonal households, hotel populations, retail employment ratios, percentage of high-income retired households) that are not easily available. The method alone is very vulnerable to missing data. In addition, a slight improvement in the accuracy was achieved in the case where the geographic location of the models was taken into account. As indicated by the existing national works $[18,19]$, a very important grouping factor is the Polish region and interactions with neighboring cities. The discriminant analysis proposed by I. Tsapakis, W. Schneider, A. Bolbol, and A. Skarlatidou [21] and the artificial neural network model proposed by T. Pamuła [11], are also based solely on quantitative variables such as time-of-day factors, daily traffic volumes or, in the case of SSN, hourly volumes; therefore, they have limited capabilities of practical use in countrywide conditions.

The aim of this article is to determine unambiguous attributes allowing for the proper assignment of road sections as it pertains specifically to Polish applications, on the basis of short-term measurements, into the appropriate group of seasonal variations. The more effective the assignment, the more accurate the estimation of design volumes, road reliability, as well as better traffic management and, consequently, an increase in the quality of road solutions.

\section{CONSTRUCTION AND VERIFICATION OF THE DATABASE}

The creation of a reliable database of the traffic volumes of road networks was the most labourintensive part of the analysis. The issues taken into consideration were limited to national rural roads of the following cross-sections: single carriageway - two-way two-lane (1x2 - one lane for traffic in each direction) and multi-lane (1x4 - two lanes for traffic in each direction) and dual carriageway multi-lane ( $2 \times 2$ - two lanes for traffic in each direction). The study used the data from permanent traffic count stations from the years 2000 to 2015, which allowed for continuous automatic recording of traffic for each category of vehicle and direction. In total, data was obtained from 86 measuring sections. In the absence of complete data, the missing traffic volumes up to two hours were input by linear interpolation and treated as complete. The lack of more than two hours in a day excludes the day from analysis. In the absence of the required number of days (for each month a minimum of 14 days was required, whereas each of the day of the week must be represented two times), the measuring station was excluded (each station has obtained, at minimum, one year's data so analyses were conducted for all 86 stations). A complement of the above-mentioned database was information about the characteristics of road sections and their environment in the zones of measuring cross-sections, which provided the following data on traffic volumes: 
- location - region of Poland (according to the breakdown resulting from forecast GDP growth rates [25]): central; south; east; northwest; southwest; north,

- technical class: A (motorways); S (expressways); GP (main roads, accelerated motion),

- cross-section: $1 \times 2 ; 1 \times 4 ; 2 \times 2$,

- interaction with neighboring cities (provincial or with a population exceeding 200,000 inhabitants): $<20 \mathrm{~km} ;>20 \mathrm{~km}$; no interaction,

- function of roads: main route connecting the north and south of Poland (yes or no); departure routes towards border crossings (yes or no); summer and winter tourism area (yes or no).

\section{ANALYSIS AND CHARACTERISTICS OF SEASONAL TRAFFIC VOLUME VARIATIONS}

In order to determine the characteristics of seasonal traffic volume variations, analyses were first performed to determine the effect of the directional distribution of traffic on the seasonal traffic volume variations. To standardize the data, analyses were carried out in relation to average share values of the daily traffic volume of each month during the annual average daily traffic (AADT). First, shares were determined for all stations for subsequent years, taking into account each group's volumes in the road cross-section and directions 1 and 2. Next, for each of the groups (for each year separately), the mean absolute percentage error (MAPE) between the determined shares was calculated: for the road cross-section and direction 1 with respect to the cross-section, and in the same way for direction 2. Analyses show that in the case of seasonal variations, the directional distribution has little effect on the share of individual months in the AADT (average MAPE $<1.1 \%$ ). In order to confirm statistical significance in the daily volumes per the individual directions, a paired difference test was performed at a significance level $\alpha=0.05$. A parametric test was used for dependent samples; a null hypothesis stating that the average value of the difference of paired figures is zero was tested. The paired data are average daily volumes of a given month of the year in direction 1 and direction 2. The result of the test indicates that, in most cases, the differences in daily volumes in the individual directions are statistically significant, but small. There is no need, therefore, to take into account the directional distribution in the case of seasonal variation. Therefore, further analyses were conducted only with respect to the road cross-section. 
In the next step of analyses, the following procedures were implemented:

- determination of seasonal variation indicators, as defined by GDDKiA - formula 3.1, separately for each station and, initially, for each year from which data is available, and then as an average of all the years. This approach allows for better avoidance of accidental impacts (movable public holidays, extreme weather conditions). Relative profiles obtained in this way will be used to divide the road network into homogeneous traffic sections,

$$
W_{j}=\frac{M A D T}{A A D T}
$$

where:

$\mathrm{W}_{\mathrm{j}}$ - monthly factor is the ratio of monthly (e.g. January) average daily traffic (MADT) to the AADT.

- division of the road network into homogeneous traffic sections, meaning those with similar traffic patterns in the analyzed period. For this purpose, a cluster analysis was used - the basic idea being to divide the objects in such a way that the degree of linkage of objects belonging to one of the groups is the largest, and, among the groups, as small as possible [20]. Cluster analysis is not a statistical test but a collection of different algorithms which group objects into clusters (detection of data structures without explaining why they occur). Due to separate analyses conducted in engineering practices regarding Two-Lane Highways, multilane Highways, and Freeways [7], division was allotted into these three groups. Based on the shape of the seasonal variation profiles and the agglomeration algorithm as well as k-means clustering, the network of national roads was divided into: three groups - A, S-class roads, and GP with cross-section 1x2; one groups - GP with cross-section $1 \times 4$ or $2 \times 2$. Details of the similar analyses are given in [19],

- determination of representative and relative traffic volume variation profiles as average values for each of the homogeneous traffic sections. In Tab. 1, a description of each traffic volume variation profile (with distinctive characteristics of the roads and their surroundings) and the sample size were presented. In further analyses, the profile symbol is associated with the seasonal variation group. It should be noted that only profile G (all cases) and T (A- and S-class roads), representing respectively $77 \%$ and $2 \%$ of the cases, is similar to the typical profile presented on the GDDKiA website [24] for the routes, respective of the economic and tourism-recreation nature of traffic patterns. Profile GT (all cases) representing $20 \%$ of the cases has a profile between two typical profile from the GDDKiA website (average difference between profiles G and GT is about $20 \%$ of AADT, so half the size of the current approach). This points to the need for a new definition of 
the so-called nature of traffic patterns (now, the division is made on the basis of Sunday and holiday traffic). Fig. 1 shows the location of permanent traffic count stations assigned to a certain group of seasonal variations (additionally, marked with a star, road sections qualified for a SFG on the basis of data from 2016 posted on the GDDKiA website),

Table 1. Description of traffic volume variation profiles and characteristics of the roads and their surroundings

\begin{tabular}{|c|c|c|c|c|c|}
\hline $\begin{array}{l}\text { Profile } \\
\text { symbol }\end{array}$ & $\begin{array}{l}\text { Variation } \\
\text { description }\end{array}$ & $\begin{array}{l}\text { Sample } \\
\text { size }\end{array}$ & Polish region & Spatial relationship & function \\
\hline \multicolumn{6}{|c|}{$\mathrm{A}$ and $\mathrm{S}$ class roads } \\
\hline \multirow{3}{*}{ G } & \multirow{3}{*}{$\begin{array}{l}\text { small seasonal } \\
\text { traffic variation }\end{array}$} & 14 & 1,4 & 4 & off the 1 \\
\hline & & 1 & 6 & 1 & 4 \\
\hline & & 9 & $2,3,5$ & 4 & 4 \\
\hline \multirow{2}{*}{ GT } & \multirow{2}{*}{$\begin{array}{l}\text { marked seasonal } \\
\text { traffic variation }\end{array}$} & 2 & 4 & 1 (outside the city of Poznan) & 4 \\
\hline & & 2 & 6 & 3 & 4 \\
\hline \multirow[t]{2}{*}{$\mathrm{T}$} & $\begin{array}{l}\text { Large seasonal } \\
\text { traffic variation }\end{array}$ & 2 & 4 & 3 & 1 \\
\hline & \multicolumn{5}{|c|}{ GP class roads $(1 \times 4$ or $2 \times 2)$} \\
\hline \multirow[t]{2}{*}{ G } & $\begin{array}{l}\text { small seasonal } \\
\text { traffic variation }\end{array}$ & 13 & 7 & 4 & 4 \\
\hline & \multicolumn{5}{|c|}{ GP class roads $(1 \times 2)$} \\
\hline \multirow{3}{*}{ G } & \multirow{3}{*}{$\begin{array}{l}\text { small seasonal } \\
\text { traffic variation }\end{array}$} & 17 & $\begin{array}{c}1 \mathrm{a}, 1 \mathrm{~b}, 3 \mathrm{a}, 3 \mathrm{~b} \\
4 \mathrm{a}, 4 \mathrm{~b}, 2,5\end{array}$ & 4 & $\begin{array}{c}4 \text {, when region } 4 \text { and } \\
2 \text { - off the } 1 \text { and } 3\end{array}$ \\
\hline & & 6 & $1 \mathrm{c}, 3 \mathrm{c}, 4 \mathrm{c}$ & $\begin{array}{c}1 \text { (including the city of } \\
\text { Koszalin), } 2,4 \text { - when function } \\
2\end{array}$ & 2,4 \\
\hline & & 6 & 6 & $1,2,4$ when function 2 & 2,4 \\
\hline \multirow{2}{*}{ GT } & \multirow{2}{*}{$\begin{array}{l}\text { marked seasonal } \\
\text { traffic variation }\end{array}$} & 11 & $1 \mathrm{c}, 3 \mathrm{c}, 4 \mathrm{c}, 6$ & 3 & off the 3 \\
\hline & & 1 & 2 & 3 & 3 \\
\hline $\mathrm{T}$ & $\begin{array}{l}\text { Large seasonal } \\
\text { traffic variation }\end{array}$ & 1 & 4 & 3 & 1 \\
\hline
\end{tabular}

Key: Polish region: 1 - central (central belt - 1a, south part - 1b, north part - 1c), 2 - south, 3 - east (central belt - 3a, south part - 3b, north part - 3c), 4 - northwest (central belt - 4a, south part - 4b, north part - 4c), 5 - southwest, 6 north, 7 - without significance.

Spatial relationship: 1 - impact of cities at a distance of $<25 \mathrm{~km}, 2$ - impact of cities at a distance of $>25 \mathrm{~km}, 3-$ outside the impact of urban agglomerations, 4 - without significance.

function of roads: 1 - main route connecting the north and south of Poland, 2 - departure routes towards border crossings, 3 - summer and winter tourism area, 4 - not specified. 


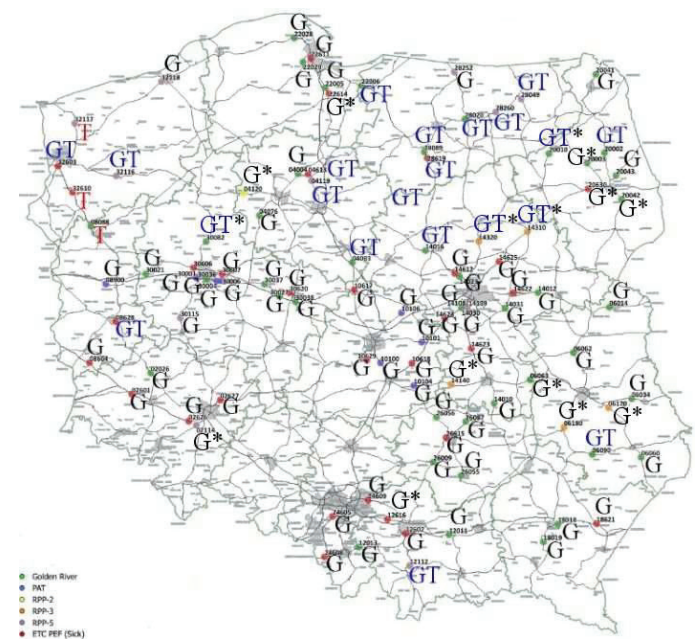

Fig. 1. Map of PTC assigned to a certain SFG (source: own study based on GDDKiA, Jakub Maśkiewicz)

- determination of the effect of public holidays. For this purpose, analyses were performed on data aggregated to daily volumes and divided into three groups: the first - every day of the year, second - without public holidays, third - without public holidays and the days directly related to them, the so-called entire "period" of days off. Days covering the entire "period", following detailed analyses of daily variation, were determined to significantly deviate from the average values. First, the annual average values (AADT) and the coefficient of variation $\varepsilon$ (formula 3.2) were calculated for each group and the difference was calculated using formula 3.3. Average difference values for all counters are shown in Tab. 2. As is evident from the analysis, the impact of public holidays on the value of annual average daily volume is insignificant in the case of all vehicles (average differences in values of all measuring points do not exceed 1.0\%). It stands to reason that the effect of public holidays is small, but not negligible.

$$
\varepsilon=\left(\frac{\sigma}{\bar{y}}\right) \times 100[\%]
$$

where:

$\varepsilon$ - coefficient of variation of the studied traffic characteristic (daily traffic volume), $\sigma$ - standard deviation of the studied traffic characteristic, - average value of the studied traffic characteristic. 


$$
d=\left(\frac{V_{\text {ph/ep }}-V_{\text {year }}}{V_{\text {year }}}\right) \times 100[\%]
$$

where:

$\mathrm{d}$ - difference between the AADT value or $\varepsilon$ determined for all days of the year and the value determined excluding public holidays or the entire "period" of days off, $\mathrm{V}_{\text {year }}$ - value of AADT or $\varepsilon$ determined for all days of the year, $\mathrm{V}_{\mathrm{ph} / \mathrm{p}}$ - value of AADT or $\varepsilon$ determined excluding, respectively, public holidays or the entire "period" of days off.

Table 2. Maximum difference [\%] between the values set for: - all days of the year, - without public holidays, - without public holidays and the days directly related to them

\begin{tabular}{|c|c|c|c|}
\hline$\left(\mathrm{AADT}_{\mathrm{bdw}}-\mathrm{AADT}\right) / \mathrm{AADT}[\%]$ & $\left(\mathrm{AADT}_{\mathrm{bco}}-\mathrm{AADT}\right) / \mathrm{AADT}[\%]$ & $\left(\varepsilon_{\mathrm{bdw}}-\varepsilon\right) / \varepsilon[\%]$ & $\left(\varepsilon_{\mathrm{bco}}-\varepsilon\right) / \varepsilon[\%]$ \\
\hline 0,74 & 0,95 & 6,85 & 9,99 \\
\hline
\end{tabular}

\section{APPLiCATION OF CALCULATION MODELS IN THE CLASSIFICATION OF ROADS TO THE APPROPRIATE SEASONAL VARIATION GROUP}

In order to confirm the dominant factors classifying rural roads into the appropriate group of seasonal variations compiled in Tab. 1, two models were used; namely, artificial neural networks and discriminant analysis. Analyses were performed on data from 2015 to unify the traffic volume in respect to the road cross-section (roads 1x2) and for the direction of movement (A- and S-class roads or multilane highways). Due to the deviation of daily volumes from the average values, public holidays and the days directly related to them were removed from the analysis. Eventually, 33,110 cases were collected regarding rush hour traffic volumes of 68 measured sections characterized by different types of seasonal variation. A grouping variable (dependent) is a group of seasonal variations, G or GT - according to Tab. 1 (because of inadequate sample size - three cases - omitted profile T).

\subsection{ARTIFICIAL NEURAL NETWORKS}

The following input variables were used:

- qualitative variables - the value of rush hour traffic volume (VOL),

- qualitative variables - the day of the week, month of the year, Polish region (central, south, east, northwest, southwest, north), spatial relationship (direct impact of urban areas at a distance of $<$ 
$20 \mathrm{~km}$, impact of urban areas at a distance of $>20 \mathrm{~km}$, outside the influence of urban areas), crosssection $(1 \times 2$ or $1 \times 4 / 2 \times 2)$, technical class (A, S, or GP) and the function of roads (departure routes towards border crossings or not - because of inadequate sample size - one case - omitted summer and winter tourism areas).

In the case of the central, east, and northwest regions, because of SFG distribution seen in Fig. 1, an additional division has been introduced : a so-called central belt (main route connecting the east and west of Poland); north part; south part. The final selection of the optimal set was made automatically using a genetic algorithm (Tab. 3).

To build the model an automatic network designer, the Statistica software, was chosen. It enables the automatic selection of a method of network learning, the number of independent variables on the input and output of the network, the number of neurons in different layers of the network, and random distribution of data into the training (70\%), validation (15\%), and test sets (15\%). As a selection criterion of the retained networks, the smallest error for a validation set was adopted. Initially, the quality of the classification of road sections was tested by neural networks of different types and with different architecture (linear networks, multilayer perceptron networks, radial basis function networks, probabilistic neural networks). It turned out that the best results are obtained with a multilayer perceptron, and therefore, ultimately, only one-way multilayer perceptron (MLP) networks with one hidden layer were used in the study. Tab. 3 shows the results of the modelling for the 3 best models obtained including network structure (the number of independent variables on the input and output of the network and the number of neurons in different layers of the network), the error ratio obtained from the sensitivity analysis for each variable in the model (impact assessment of independent variables), and the rank - in decreasing order - of the error ratio. All selected variables exhibit statistical significance, which supports their functional selection. In all cases, the highest value of the error ratio (the lowest rank) was obtained for variables Polish region (including additional breakdown due to the central belt), spatial relationship, and function of road. The lowest value of the error ratio was obtained for variables the day of the week and month of the year. Among the analyzed networks, the best quality was obtained for model MLP 39-9-2 - marked in bold in Tab. 3. The coefficient of correct classification, amounting to 1.0 for all three subsets (training, validation, and test set) in each of the cases, proves excellent efficiency of the networks. Small errors of training and validation sets $(0.00$ and 0.02$)$ testify to the valid generalization properties of the networks. Table 4 shows the statistics for classification problems (compliance of classification of individual cases). As it can be seen, $100 \%$ of the cases were correctly classified into the appropriate seasonal variation group (according to Fig. 1). 
Tab. 3. Sensitivity analysis for artificial neural network models

\begin{tabular}{|c|c|c|c|c|c|c|c|c|c|c|}
\hline type an & $\begin{array}{l}\text { ructure of the } \\
\text { work }\end{array}$ & $\stackrel{0}{>}$ & ते & $\begin{array}{l}\text { E्ञ } \\
\text { ఏ }\end{array}$ & 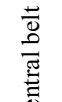 & 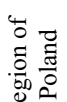 & 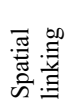 & 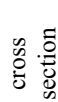 & 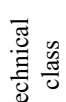 & 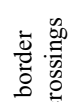 \\
\hline $39-11-2$ & Error Ratio & 3 & 1 & 1 & 244 & 121 & 204 & 10 & 9 & 168 \\
\hline $39-11-2$ & Rank & 7 & 8 & 9 & 1 & 4 & 2 & 6 & 5 & 3 \\
\hline $39-6-2$ & Error Ratio & 16 & 1 & 1 & 848 & 497 & 1066 & 155 & 12 & 583 \\
\hline $39-6-2$ & Rank & 7 & 8 & 9 & 2 & 4 & 1 & 5 & 6 & 3 \\
\hline $30-0=$ & Error Ratio & 36 & 1 & 1 & 7405 & 4515 & 9004 & 169 & 2706 & 5186 \\
\hline $39-9-2$ & Rank & 7 & 8 & 9 & 2 & 4 & 1 & 5 & 6 & 3 \\
\hline
\end{tabular}

Tab. 4. Classification statistics for the best SSN model

\begin{tabular}{|c|c|c|}
\hline & Profile G & Profile GT \\
\hline All & 20024 & 3154 \\
\hline Correct & 20024 & 3154 \\
\hline Incorrect & 0 & 0 \\
\hline Correct (\%) & 100 & 100 \\
\hline Incorrect (\%) & 0 & 0 \\
\hline
\end{tabular}

\subsection{DISCRIMINANT ANALYSIS}

In the case of discriminant analysis, independent variables which showed the value of the error ratio in the sensitivity analysis for ANN models (more than 1 - Tab. 3) were used. Since these variables are both continuous (the value of rush hour traffic volume) and qualitative (Polish region, spatial relationship, cross-section, technical class, function of roads), general discriminant analysis was taken advantage of in the analyses. Calculations were performed using Statistica software. Due to the omission of the variables day of the week and month of the year, the number of analyzed cases was limited to 68 (VOL - value of measurement adopted in the analysis for Wednesday in September). Due to the lack of studies in known literature regarding the use of the method of the best subset in a relationship with qualitative predictors [20], this analysis should not be treated as statistical analysis. Tab. 5 shows a summary of the results of the classification. The first column shows the percentage of cases which were correctly classified, while the remaining columns contain the number of cases classified into the appropriate groups. As it can be seen, road sections were classified $100 \%$ correctly into the appropriate seasonal variation groups (according to Fig. 1). 
Tab. 5. Classification matrix of discriminant analysis

\begin{tabular}{|c|c|c|c|}
\hline class & $\begin{array}{c}\text { Percentage of } \\
\text { correct } \\
\text { classification }\end{array}$ & $\begin{array}{c}\text { Profile } \\
\text { G }\end{array}$ & $\begin{array}{c}\text { Profile } \\
\text { GT }\end{array}$ \\
\hline Profile G & 100,0 & 57 & 0 \\
\hline Profile GT & 100,0 & 0 & 11 \\
\hline All profiles & 100,0 & 57 & 11 \\
\hline
\end{tabular}

\section{CONCLUDING REMARKS}

The conducted computational experiments (neural network, general discriminant) have shown that on the basis of the identified features of traffic, roads, and their surroundings, it can be $100 \%$ correctly classified which road sections belong to the appropriate seasonal variation types. These results indicate the correct assignment of the impact of these features on seasonal variation. The highest value of the quotient error was obtained for qualitative variables associated with the location of a particular section of road (Polish region, including additional breakdown due to the so-called central belt, spatial relationship, and departure routes towards border crossings), which shows its greatest impact on the quality of the ANN built. Similarly, for other variables selected (value of rush hour traffic volume, cross-section, and technical class) statistical significance was obtained, which proves that their selection was correct. On the other hand, studies indicate that some features of traffic bring little important information, and can therefore be omitted. These variables are: day of the week and month of the year. According to the results of previous studies which sought model relationships between the characteristics of traffic volume variations with time and AADT, taking into account the characteristics of the roads and their surroundings $[18,19]$, the most important factors are qualitative variables associated with the location of the road section and less important qualitative variables such as the technical class and cross-section as well as quantitative VOL. In order to further verify the obtained results, especially in the northwest and southwest regions of Poland where only a few PTCs are located (excluding the so-called central belt, only 15 stations), the GPR2015 data was analyzed. Comparing the ratio of average daily traffic in July and August to the annual average daily traffic, sections with similar characteristics to profile G and GT were identified (respectively, ratio lower than 1.20 and between 1.20 and 1.55). The upper value of 1.55 , which is connected with profile $T$, has not been identified. The obtained results are shown in Fig. 2. It can be noted that profile GT (northwest region), occurs only on routes leading to coastal cities such as Ustka, Kolobrzeg, or Swinoujscie, and on the main route connecting the north and south of Poland (S3) but only to the area of the city of Zielona Gora, which complements the previous analysis. The only divergence from earlier analyses occurs in the case of station 32116, which was classified to a GT profile based on 
cluster analysis, but it was an ambiguous case located at the boundary of two clusters while assigning one direction to a G profile and the other to a GT (the only such case). In the Pomeranian and Kuyavian-Pomeranian counties, the GT profile occurs only within A1 (up to the area of the city of Lodz) and DK7 (DK91 was not confirmed), which may indicate the need for additional division of the northern region. On the other hand, results of GPR2015 are based on short-term measurements and are subject to a high risk of error, so research should continue (it has been shown that the use tools are useful in the analysis of traffic data and may be helpful in future studies, as the available traffic data will successively increase). In the case of the southwest region of Poland, profile GT has not been identified, which is consistent with earlier findings. It can therefore be concluded that, based on the measurement of rush hour traffic volumes and section location (unique values), the road section can be effectively assigned to the proper seasonal variation group. This approach is a departure from traditional methods, which are mainly based on quantitative variables (dependent on traffic). Due to the promising result of the analysis, the present approach can be used by road administration entities as a supporting tool for the definition of SFG, which allows for a decrease in the need of engineering judgment (which is often subjective). It should also be noted that the currentlyrecommended division of rural roads into two seasonal factor groups is insufficient. The differences between typical profiles posted on the website exceed $40 \%$ of the AADT value, while for the presented G and GT profiles (representative of $97 \%$ of the cases) the difference does not exceed $26 \%$. This means that $3 \%$ of the roads of a typical recreational nature (traffic in the summer months is higher by at least $60 \%$ of AADT and could reach even $90 \%$ ) should be analyzed individually, as they have a decisive influence on the shape of a profile for tourist-recreational roads.

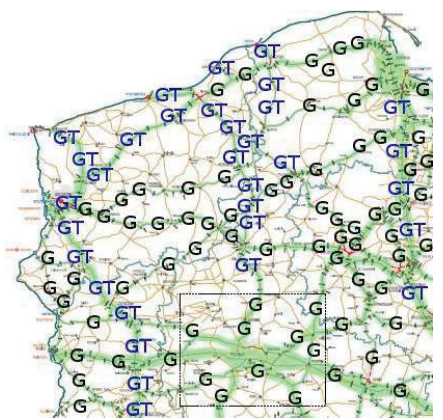

Fig. 2. Map of SFG determined on the basis of the results GPR2015 (source: own study based on [14]) 
Research performed under the project "Modern methods of calculating the road capacity and assessment of traffic conditions of roads outside municipal agglomerations, including express roads" financed by NCBiR/GDDKiA as a part of a common undertaking "RID", under contract DZP/RIDI-50/9/NCBR/2016.

\section{REFERENCES}

1. AASHTO Guidelines for Traffic Data Programs, American Association of State Highway and Transportation Officials, 1992

2. K. W. Axhausen, B. Jäggi, Ch.: DoblerBemessungsverkehrsstärken: Einneuer Ansatz. Forschungsprojekt VSS 2011/103 auf Antrag des SchweizerischenVerbands der Strassen und Verkehrsfachleute (VSS). Zürich, Juli 2015

3. P. H. Bellamy.: Seasonal Variations in Traffic Flows, Supplementary Report 437, prepared for the Department of the Environment and the Department of Transport, Prepared by Traffic Engineering Department, Transport and Road Research Laboratory, Berkshire, Great Britain, 1978

4. A. Faghri, J. Hua: Roadway Seasonal Classification Using Neural Network. Journal of Computing in Civil Engineering, Vol. 9, No.3, 1995, s. $209 \div 215$

5. Federal Highway Administration (FHWA), Traffic Monitoring Guide, 2013

6. M. Gastaldi, G. Gecchele, R. Rossi "Estimation of Annual Average Daily Traffic from one-week traffic counts a Combined ANN-Fuzzy approach" Transportation Research Part C 47 (2014) 86-99

7. Highway Capacity Manual, Sixth Edition: A Guide for Multimodal Mobility Analysis. Washington, D.C.: Transportation Research Board 2017

8. M. T. Li, F. Zhao, Y. Wu: Application of Regression Analysis for Estimating Seasonal Factors in Southeast Florida. Transport Research Record 1870, Washington DC 2004, s. $153 \div 161$

9. P. Lingras: Classifying Highways: Hierarchical Grouping versus Kohonen Neural Networks. Journal of Transportation Engineering, 07/08.1995, s. $364 \div 368$.

10. P. Lingras: Statistical and Genetic Algorithms Classification of Highways. Journal of Transportation Engineering, Vol. 127, No.3, 2001, s.237 $\div 243$

11. T. Pamuła: Classification and Prediction of Traffic Flow Based on Real Data Using Neural Networks. Archives of Transport, No. 12/2012, pp.519-529

12. L. Pinkofsky: Typisierung von Ganglinien der Verkehrsstärke Und ihreEignungzurModellierung der Verkehrsnachfrage. Dissertation, TechnischeUniversitatBraunschweig, Aachen 2006

13. S. G. Ritche: A Statistical Approach to Statewide Traffic Counting. Transportation Research Record 1090, Washington, DC, 1986, s. $14 \div 21$

14. Ruch Drogowy 2015, GDDKiA, Warszawa 2016

15. S. C. Sharma: Improved Classification of Canadian Primary Highways According to Type of Road Use. Canadian Journal of Civil Engineering, Vol. 10, No.3, 1983, s. $497 \div 509$

16. S. C. Sharma, P. J. Lingras, M. U. Hassan, N. A. Murthy: Road Classification According to Driver Population. Transportation Research Record 1090, Washington, DC, 1986, s. 61 $\div 69$

17. SHRP 2 - L08: Incorporation of Travel Time Reliability into the HCM, August 2013

18. M. Spławińska: Models for determining annual average daily traffic on the national roads, Archives of Civil Engineering, nr 2/2015, s. 141 - 158

19. M. Spławińska: Characteristics of traffic flow variability and their impact on AADT. LAP Lambert Academic Publishing, 2015

20. A. Stanisz: Przystępny kurs statystyki z zastosowaniem STATISTICA PL na przykładach z medycyny, tom III. Kraków 2007

21. I. Tsapakis, W. Schneider, A. Bolbol, A. Skarlatidou: Discriminant Analysis for Assigning Short-Term Counts to Seasonal Adjustment Factor Groupings. Transportation Research Record: Journal of the Transportation Research Board 2256, Washington DC 2011, s. $112 \div 119$

22. Verkehrsentwicklung auf Bundesfernstaben 2007. Berichte der Bundesanstalt fur Strabenwesen, Verkehrstechnik Heft V 178 
23. M. Li, F. Zhao, L. Chow. Assignment of Seasonal Factor Categories to Urban Coverage Count Stations Using a Fuzzy Decision Tree. ASCE Journal of Transportation Engineering, Vol. 132, No. 8, 2006, pp. 654-662

24. http://www.gddkia.gov.pl/userfiles/articles/s/stacje-ciaglych-pomiarow-ruchu-d_26174/R02_05_2016.pdf

25. https://www.gddkia.gov.pl/userfiles/articles/p/pismo-przewodnie-z-dnia-

15032007_4423/Zalacznik_3_Prognozy_wzrostu_PKB_2008-40_poprawa_kodow_nts.pdf

\section{LIST OF FIGURES AND TABLES:}

Fig. 1 Map of PTC assigned to a certain SFG (source: own study based on GDDKiA, Jakub Maśkiewicz) Rys. 1. Mapa lokalizacji SCPR wraz z przynależnością do odpowiedniej SFG (źródło: opracowanie własne na podstawie GDDKiA, Jakub Maśkiewicz)

Fig. 2. Map of SFG determined on the basis of the results GPR2015 (source: own study based on [14])

Rys. 2. Mapa SFG wyznaczonych na podstawie wyniku GPR2015 (źródło: opracowanie własne na podstawie [14])

Tab. 1. Description of traffic volume variation profiles and characteristics of the roads and their surroundings Tab. 1. Opis profili zmienności natężeń ruchu oraz cech charakterystycznych dróg i ich otoczenia

Tab. 2. Maximum difference [\%] between the values set for: - all days of the year, - without public holidays, - without public holidays and the days directly related to them

Tab. 2. Maksymalna różnica [\%] pomiędzy wartościami wyznaczonymi dla: - wszystkich dni w roku, - bez dni ustawowo wolnych, - bez dni ustawowo wolnych wraz z dniami bezpośrednio z nimi związanymi Tab. 3. Sensitivity analysis for artificial neural network models

Tab. 3. Analiza wrażliwości dla modeli sztucznych sieci neuronowych

Tab. 4. Classification statistics for the best SSN model

Tab. 4. Statystyki klasyfikacyjne dla najlepszego modelu SSN

Tab. 5. Classification matrix of discriminant analysis

Tab. 5. Macierz klasyfikacji ogólnej analizy dyskryminacyjnej 


\section{CZYNNIKI DECYDUJĄCE O ZMIENNOŚCI SEZONOWEJ NATĘŻEŃ RUCHU}

Słowa kluczowe: drogi, natężenie ruch, zarządzanie ruchem, klasyfikacja natężeń ruchu, zbieranie danych

\section{STRESZCZENIE:}

Ciągła automatyczna rejestracja ruchu drogowego dostarcza wielu cennych informacji niezbędnych do celów planistycznych, projektowych i eksploatacyjnych odcinków i skrzyżowań drogowych. Dzięki temu możliwe jest określenie sezonowych wahań ruchu umożliwiających wykonanie uproszczonych przeliczeń natężeń z pomiarów krótkotrwałych na średni dobowy ruch w roku (SDR). W praktyce, dokonuje się podziału sieci dróg na tzw. grupy zmienności sezonowej (SFG) i wyznacza się dla nich wskaźniki przeliczeniowe natężeń dobowych na SDR. Ponadto charakterystyki te wykorzystywane są w analizach niezawodności sieci dróg [17], w nowym podejściu wyznaczenia natężeń miarodajnych w oparciu o uogólnione koszty (analizy ekonomiczne) [2] a także są przydatne w podejmowaniu decyzji w Inteligentnych Systemach Transportowych i zarządzaniu ruchem. W Polsce obecnie wyróżnia się dwie grupy SFG tj. drogi o gospodarczym i turystyczno-rekreacyjnym charakterze przenoszonego ruchu [14], co w świetle wcześniejszych analiz $[18,19]$ wydaje się zbyt dużym uogólnieniem. Klasyfikacji odcinków do danej grupy dokonuje się na podstawie ruchu niedzielnego oraz wakacyjnego. Drogi o gospodarczym charakterze przenoszonego ruchu charakteryzują się występowaniem niewielkich sezonowych wahań ruchu oraz średnim dobowym ruchem w niedziele mniejszym niż 140\% wartości średniego dobowego ruchu w dni robocze, natomiast drogi o turystyczno-rekreacyjnym charakterze - ruchem w miesiącach wakacyjnych (VII, VIII) ponad 40\% większym od SDR lub średnim dobowym ruchem w niedziele większym niż 140\% wartości średniego dobowego ruchu w dni robocze. Jak widać jest to bardzo nieprecyzyjna informacja trudna do stwierdzenia bez znajomości natężeń ruchu pochodzących z dłuższego okresu. Celem artykułu jest zatem określenie dla warunków polskich, jednoznacznych atrybutów umożliwiających przydzielenie odcinka drogi, na podstawie pomiarów krótkotrwałych, do odpowiedniej grupy zmienności sezonowej. Większa skuteczność przydzielenia przełoży się bezpośrednio na większą dokładność szacowania natężeń miarodajnych, niezawodność dróg, lepsze zarządzanie ruchem, a w konsekwencji umożliwi podniesienie jakości rozwiązań drogowych. Badania prowadzono na danych pochodzących ze stacji ciągłego pomiaru ruchu z lat $2000-2015$. W celu potwierdzenia dominujących czynników klasyfikujących (zestawionych w tab. 1) drogi zamiejskie do odpowiedniej grupy zmienności sezonowej, zastosowano dwa modele tj. sztuczne sieci neuronowe i ogólną analizę dyskryminacyjną a także wykorzystano wynik GPR2015 (metoda graficzna). Zmienną grupującą (zależną) stanowi grupa zmienności sezonowej, G lub GT - zgodnie z tab. 1. W przypadku modeli sztucznych sieci neuronowych (SSN), wykorzystano następujące zmienne wejściowe: ilościowe (natężenie godziny szczytu), zmienne jakościowe (dzień tygodnia, miesiąc w roku, region Polski, przekrój poprzeczny, klasa techniczna, powiązanie przestrzenne oraz funkcja drogi). W przypadku analizy dyskryminacyjnej wykorzystano zmienne niezależne, które wykazały wartość ilorazu błędu w analizie wrażliwości dla modeli SSN, większą od 1 - tab. 3. Przeprowadzone eksperymenty obliczeniowe (sztuczne sieci neuronowe, analiza dyskryminacyjna) wykazały, że na podstawie wyróżnionych cech ruchu, drogi i jej otoczenia w 100\% można poprawnie zakwalifikować odcinek drogi do odpowiedniego typu zmienności sezonowej. Można zatem stwierdzić, że na podstawie natężenia godziny szczytu oraz lokalizacji odcinka oraz typu przekroju poprzecznego i klasy technicznej (jednoznaczne wartości) można skutecznie przydzielić odcinek drogi do odpowiedniej grupy zmienności sezonowej. Podejście to stanowi odejście od tradycyjnych metod, w których opiera się głównie na zmiennych ilościowych (zależnych od natężenia 
ruchu). Ze względu na obiecujące wyniki, zaprezentowane podejście może znaleźć zastosowanie przez administrację drogową jako narzędzie wspomagające do zdefiniowania SFG. 